\title{
Photoperiod and melatonin influence seasonal gonadal cycles in the grasshopper mouse (Onychomys leucogaster)
}

\author{
Darlene Frost and I. Zucker \\ Department of Psychology, University of California, Berkeley, California 94720, U.S.A.
}

\begin{abstract}
Summary. Development of the reproductive apparatus was delayed in grasshopper mice maintained from birth in short photoperiods ( $10 \mathrm{~h} \mathrm{light/day).} \mathrm{The} \mathrm{inhibitory}$ effects of short photoperiods on sexual maturation eventually waned and mice in 10L :14D became reproductively active. Adult mice transferred from long $(14 \mathrm{~h}$ light/day) to short photoperiods underwent testicular regression after 10 weeks and complete gonadal redevelopment after 30 weeks. A similar phenomenon was observed in adult female mice; oestrous cycles ceased within 3 weeks and resumed after 13 weeks in the short photoperiod. The regressive effects of short photoperiods on the male reproductive system were mimicked by daily injections of melatonin administered to mice housed in $14 \mathrm{~L}: 10 \mathrm{D}$. Responsiveness of the female reproductive system to melatonin was reduced among photorefractory as compared to photosensitive mice. We suggest that the initial rate of sexual maturation and the timing of seasonal breeding in adult mice are regulated by photoperiod; effects of short daylengths on the neuroendocrine-reproductive axis appear to be mediated by the pineal gland.
\end{abstract}

\section{Introduction}

Photoperiod, food availability and temperature influence reproductive cycles of mammals (Sadleir, 1969; Negus \& Berger, 1972; Zucker, Johnston \& Frost, 1980). Temperate-zone rodents in relatively predictable habitats often rely on photoperiod as the major proximate stimulus for regulation of seasonal reproductive cycles. The importance of annual variations in daylength for reproduction was first demonstrated for the field vole, Microtus agrestis (Baker \& Ranson, 1932). Since then, studies with several other species have established that the minimum daily light duration sufficient to maintain reproduction varies between 12 and 16 h (Elliott, 1976; Lynch \& Gendler, 1980; Grocock, 1981; Dark, Johnston, Healy \& Zucker, 1983). Animals maintained in photoperiods that fall below the threshold value characteristically have aspermatic testes, reduced plasma testosterone and gonadotrophin titres and manifest reduced copulatory behaviour (reviewed by Turek \& Campbell, 1979; Zucker et al., 1980; Reiter, 1980; Follett \& Follett, 1981). Photoperiodic phenomena have been much less extensively documented for female than for male rodents; however, reproductive behaviour and physiology of females and males appear to respond in an analogous fashion (see Seegal \& Goldman, 1975; Reiter, 1980).

Much of the substantive information concerning regulation of the reproductive apparatus of rodents by photoperiod is derived from studies of the Syrian hamster (Mesocricetus auratus) (reviewed by Reiter, 1980; Elliott \& Goldman, 1981). Studies of other rodent species reveal pronounced variations in photoperiodic regulation of seasonal reproductive cycles. For example, development of the reproductive apparatus is independent of photoperiod in Syrian hamsters (Reiter, Sorrentino \& Hoffman, 1970; Rissman, 1980) but regulated by daylength in Djungarian 
hamsters, white-footed mice, deer mice and several species of voles (Lecyk, 1962; Hoffmann, 1978; Johnston \& Zucker, 1980a; Whitsett \& Miller, 1982; Dark et al., 1983). Furthermore, pinealectomy has opposite effects on the reproductive apparatus of Syrian and Turkish hamsters maintained in long photoperiods (Carter, Hall, Tamarkin \& Goldman, 1982).

The formulation of a general theory of rodent photoperiodism will require reliable data from a variety of species. With this goal in mind we investigated the northern grasshopper mouse (Onychomys leucogaster). This cricetid rodent inhabits the western United States where it exhibits striking seasonal reproductive cycles; most litters are born between March and August (Egoscue, 1960 ; Flake, 1974). The results of some of the experiments reported have been briefly mentioned in the review by Zucker et al. (1980).

\section{Materials and Methods}

Northern grasshopper mice (Onychomys leucogaster) from an outbred laboratory colony were provided with tap water and food (Purina Mouse Breeder chow) ad libitum. This diet was supplemented weekly with lettuce, raw sunflower seeds and wild bird seed. Room temperature was maintained at $23 \pm 2^{\circ} \mathrm{C}$.

Surgical procedures were performed under anaesthesia induced by $L$. A. Thesia (HaverLockhart, Shawnee, Kansas) in a dosage of $0.035 \mathrm{ml} / 10 \mathrm{~g}$ body weight, i.p; this anaesthetic contains pentobarbitone sodium $(30 \mathrm{mg} / \mathrm{ml})$ and chloral hydrate $(60 \mathrm{mg} / \mathrm{ml})$.

Laparotomies. An abdominal incision was made and the right testis withdrawn. Testis length and width were measured to the nearest $0.1 \mathrm{~mm}$ with a micrometer. The testis was irrigated with saline $(9 \mathrm{~g} \mathrm{NaCl} / 1)$, returned to the abdominal cavity and the wound repaired. Nitrofurazone powder (Furacin) was applied between the muscle wall and the outer skin layer.

The testis index (TI) was computed as the maximum testicular length $\times$ width (in mm) divided by the animal's body weight (in g). The testicular index of grasshopper mice is highly correlated with paired testes weights (Text-fig. $1, r=0.94, P<0.001$ ) and is a valid indicator of testicular weight. Use of the testicular index permits repeated measurements of the testes of individual animals. A testicular index of $\geqslant 2.3$ is considered indicative of functional gonadal activity.

Histological analyses. Tissues were fixed in Bouin's solution and subsequently dehydrated, embedded in paraffin wax, sectioned at $4 \mu \mathrm{m}$ and stained with haematoxylin and eosin. The functional state of the testes was assessed by rating slides according to criteria described by Grocock \& Clarke (1974). Briefly, a spermatogenic index was calculated with numerical values

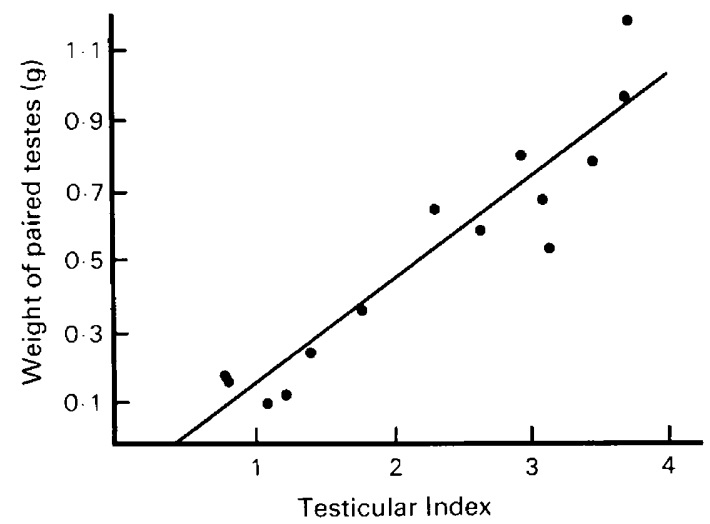

Text-fig. 1. Paired testicular weight as a function of the testicular index (see text) of grasshopper mice. 
ranging from 5 (large seminiferous tubules with complete spermatogenesis) to 0 (only Sertoli cells and spermatogonia detectable). Ovarian tissue was examined for the presence of follicles and corpora lutea.

Statistical analysis. Differences between groups were assessed with two-tailed $t$-tests for independent samples or with $\chi^{2}$ tests; within group differences were evaluated with two-tailed $t$ tests for dependent samples.

\section{Procedures}

Experiment 1. Breeding pairs were housed one per cage in a room illuminated for $14 \mathrm{~h}$ daily (lights on at $08: 00 \mathrm{~h}$, Pacific Daylight Time, 14L:10D). Within $24 \mathrm{~h}$ of birth of a litter, mice were transferred to a short-day photoperiod (10L:14D) with lights on at $11: 00 \mathrm{~h}$ daily, or were maintained in the original long-day photoperiod. At 2 days post partum, adult males were removed from the cages and at 25-28 days of age the young were weaned and housed individually in the appropriate photoperiods. Laparotomies of males were performed at 50,70, 100,120 and 150 days of age. For mice subjected to repeated laparotomies, the left and right testes were alternately externalized for successive measurements. At each age several animals selected at random from each group were killed; testes were weighed and prepared for histological analysis. For females, vaginal smears were obtained daily from $50(\mathrm{~N}=7)$ or $70(\mathrm{~N}=24)$ days of age until the animals were 90,120 or 150 days old. The females were then killed, the reproductive tissues weighed and the ovaries prepared for histological examination. Fourteen animals for which the oestrous cycles were not monitored were killed at 90,120 or 150 days. Tissues were removed without reference to the stage of the oestrous cycle.

Experiment 2. Male mice were maintained from birth in $14 \mathrm{~L}: 10 \mathrm{D}$. Beginning at approximately 135 days of age mice were housed individually and provided with cotton batting for nesting material. After 11 days (designated Week 0), 6 mice were transferred to 10L:14D and 6 mice remained in 14L:10D. All animals were laparotomized at Weeks 10 and 30. At Week 33 all mice were subcutaneously implanted with Silastic capsules (Dow-Corning; $1.47 \mathrm{~mm}$ i.d. $\times 1.96 \mathrm{~mm}$ o.d.) filled to a length of $25 \mathrm{~mm}$ with melatonin. At Week 43 the mice were killed and the gonads removed, weighed and prepared for histological analysis.

Experiment 3. Male mice, at least 8 months of age, were housed in 14L:10D. Baseline testicular index values were determined for all animals; thereafter mice were injected daily at $18: 30 \mathrm{~h}$ with 25 $\mathrm{mg}$ melatonin dissolved in sesame oil in an injection volume of $0.05 \mathrm{ml}(\mathrm{N}=7)$ or with an equivalent volume of the oil vehicle $(\mathrm{N}=10)$. Animals were autopsied after 7 weeks of treatment.

Experiment 4. Female mice, at least 6 months of age, were housed individually in 14L:10D. Vaginal smears were obtained daily for 1 month (baseline period). Mice were then divided into two groups and transferred to a room with $14 \mathrm{~L}: 10 \mathrm{D}(\mathrm{N}=10)$ or one with $10 \mathrm{~L}: 14 \mathrm{D}(\mathrm{N}=9)$. Vaginal smears were obtained for 6 consecutive weeks; after a recess of 7 weeks, vaginal smearing was reinstated for 8 weeks. Females that were still undergoing oestrous cycles were then given subcutaneous implants of melatonin (see Exp. 2). Testing for oestrous cycles was reinstated on a daily basis beginning 7 weeks after the melatonin implants were in place and was continued for 27 days. Mice were autopsied at the end of 10 weeks of melatonin treatment; ovaries and uteri were weighed and ovaries prepared for microscopic examination.

\section{Results}

\section{Experiment 1: development of the reproductive system}

Males. Short daylengths $(10 \mathrm{~L}: 14 \mathrm{D})$ retarded development of the reproductive apparatus. The testicular indexes were lower for mice in $10 \mathrm{~L}: 14 \mathrm{D}$ than in $14 \mathrm{~L}: 10 \mathrm{D}$ at 70 days of age $(P<0.003$; Text-fig. 2) and at each time point sampled up to 120 days of age $(P<0.001)$. By 150 days the 


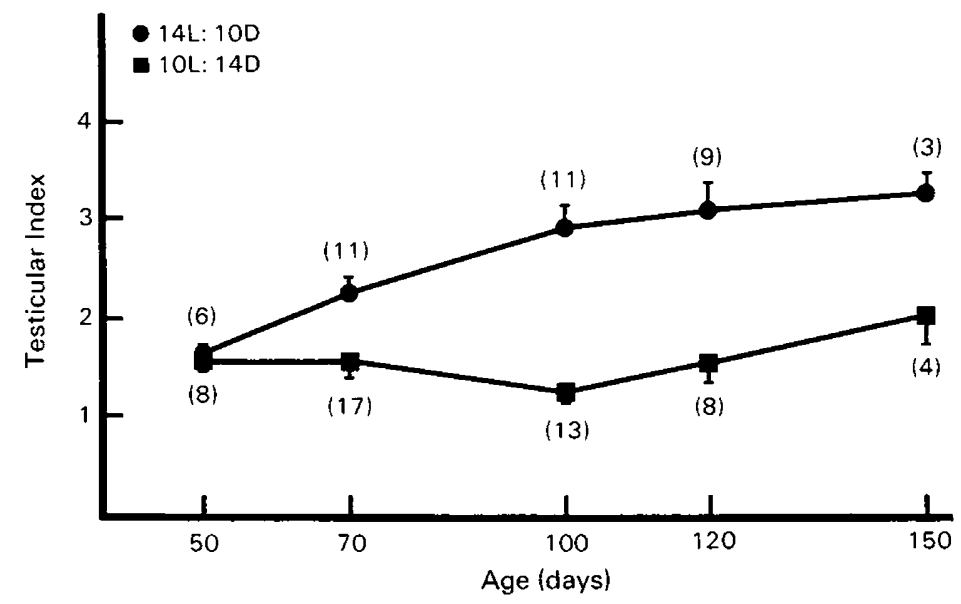

Text-fig. 2. Testicular index (mean \pm s.e.m.) of grasshopper mice as a function of age and photoperiod. Mice were exposed from birth to long or short photoperiods. Sample size is indicated in parentheses.

difference between the groups was reduced but the indexes for males in 10L:14D were still lower than those of males in $14 \mathrm{~L}: 10 \mathrm{D}(P<0.03)$.

Complete spermatogenesis, defined as stages 4 and 5 of Grocock \& Clarke (1974), was detectable in testes of all 5 mice in $14 \mathrm{~L}: 10 \mathrm{D}$ and in none of the $610 \mathrm{~L}: 14 \mathrm{D}$ animals sampled at 70 days of age. The spermatogenic index (SI) was $4.8 \pm 0.2$ and $1.8 \pm 0 \cdot 3$, respectively for the two groups $(P<0.001)$. At 100 days of age all $414 \mathrm{~L}: 10 \mathrm{D}$ males and 2 of $610 \mathrm{~L}: 14 \mathrm{D}$ males achieved stages 4 and 5 of spermatogenesis; the SI values were $4.8 \pm 0.3$ and $2.3 \pm 0.7(P<0.03)$. Although too few animals provided SI data to permit separate analyses at 120 and 150 days, combining results for these ages indicated that 6 of $710 \mathrm{~L}: 14 \mathrm{D}$ and 6 of $814 \mathrm{~L}: 10 \mathrm{D}$ mice had complete spermatogenesis. Thus, complete spermatogenesis was first detected in at least $75 \%$ of males in $14 \mathrm{~L}: 10 \mathrm{D}$ at 70 days of age and in mice in 10L:14D at 120-150 days of age.

Body weights did not differ consistently between mice in the two photoperiods, except that at 120 days mice in $10 \mathrm{~L}: 14 \mathrm{D}$ weighed more than mice in $14 \mathrm{~L}: 10 \mathrm{D}(33 \cdot 2 \pm 2 \cdot 7$ compared with $27 \cdot 5 \pm$ $1.1 \mathrm{~g}, P<0.05$ ).

Females. Short daylengths did not interfere with onset of vaginal oestrus. The first oestrous vaginal smear was detected at $72.4 \pm 6.3$ days for mice in $14 \mathrm{~L}: 10 \mathrm{D}$ and at $84.7 \pm 8.8$ for mice in 10L :14D $(P>0.05)$. Thereafter, 6 of 8 mice in $14 \mathrm{~L}: 10 \mathrm{D}$ and 2 of 10 mice in $10 \mathrm{~L}: 14 \mathrm{D}$ had regular oestrous cycles $\left(\chi^{2}\right.$ test, $\left.P<0.05\right)$. Cycles were shorter $(P<0.02)$ for mice in $14 \mathrm{~L}: 10 \mathrm{D}(8.8 \pm 0.9$ days) than for those in $10 \mathrm{~L}: 14 \mathrm{D}$ (15.6 \pm 3.6 days).

Uteri of mice in $14 \mathrm{~L}: 10 \mathrm{D}$ were heavier than those of animals in $10 \mathrm{~L}: 14 \mathrm{D}$ at 90 days $(P<0.001)$ and at 150 days $(P<0 \cdot 03)$. Ovaries were heavier in mice in $14 \mathrm{~L}: 10 \mathrm{D}$ than in mice in $10 \mathrm{~L}: 14 \mathrm{D}$ at 90 days $(P<0.002)$, but not in older animals.

At 90 days of age corpora lutea were present in ovaries of 1 of 6 and 4 of 6 mice in 10L:14D and $14 \mathrm{~L}: 10 \mathrm{D}$, respectively; corresponding values were 2 of 8 and 3 of 8 at 120 days and $5 / 7$ and $5 / 5$ at 150 days.

\section{Experiment 2: testicular regression and redevelopment in short photoperiods}

Short days induced testicular regression by Week 10 and permitted testicular redevelopment by Week 30. The testicular indexes of the 6 mice in 14L:10D did not change significantly over the course of 30 weeks $(3.4 \pm 0.3,3 \cdot 3 \pm 0.2$ and $3.2 \pm 0.4$ at Weeks 0,10 and 30). In contrast, transfer from $14 \mathrm{~L}: 10 \mathrm{D}$ to $10 \mathrm{~L}: 14 \mathrm{D}$ resulted in substantial testicular regression $(P<0.001)$ within 10 weeks 
$(2 \cdot 7 \pm 0 \cdot 1$ at Week 0 to $1 \cdot 3 \pm 0 \cdot 1$ at Week 10$)$. With continued maintenance in $10 \mathrm{~L}: 14 \mathrm{D}$ the testes redeveloped and exceeded baseline values by Week $30(3 \cdot 1 \pm 0 \cdot 3, \mathbf{N}=6)$. Week 30 values were greater than those at Week $10(P<0.005)$.

Response to melatonin-filled capsules. Treatment for 10 weeks with melatonin in Silastic capsules did not affect the testicular index values of mice in either photoperiod. Values before (Week 33) and after (Week 43) treatment were 2.64 and 2.57 for mice $(\mathrm{N}=3)$ in $14 \mathrm{~L}: 10 \mathrm{D}$ and $3 \cdot 14$ and 2.81 for those $(\mathrm{N}=3)$ in $10 \mathrm{~L}: 14 \mathrm{D}$. The absence of an effect was confirmed by observations of complete spermatogenesis in all histological sections examined from animals treated with melatonin. Findings from several additional animals, for which testicular index data were not tabulated because of testicular adhesions or ruptures, confirmed these results.

\section{Experiment 3: effects of timed melatonin injections}

The testes of mice injected once daily with melatonin regressed, unlike those of animals treated with the oil vehicle alone. Before treatment, the testicular index values of the two groups were not different $(2 \cdot 7 \pm 0.1$ and $2 \cdot 8 \pm 0.2$ for $\mathrm{N}=7$ and $\mathrm{N}=10$, respectively) but after 7 weeks of injections mice receiving melatonin had significantly reduced values $(1 \cdot 2 \pm 0 \cdot 1$ compared to $2.4 \pm$ $0 \cdot 2, P<0.001$ ).

Four of the mice treated with melatonin had testes containing mostly Sertoli cells, spermatogonia and spermatocytes; 2 mice had moderately regressed testes with smaller than normal numbers of spermatozoa and elongate spermatids and the remaining animal had normal spermatogenesis. Several mice selected at random from the oil-treated group had testes with large seminiferous tubules that contained a full complement of spermatozoa and elongate spermatids (stages 4 and 5).

\section{Experiment 4: cessation of oestrous cycles in short photoperiods}

During the 30-day baseline period in $14 \mathrm{~L}: 10 \mathrm{D}$, cycle lengths were $4.9 \pm 0.3$ and $4.9 \pm 0.4$ days for mice subsequently assigned to the long and short photoperiods (based on 33 and 40 cycles, respectively). During the first 6 weeks of differential treatment, mice in $14 \mathrm{~L}: 10 \mathrm{D}$ exhibited a mean of 7 oestrous cycles of $5 \cdot 6 \pm 0 \cdot 3$ days. None of these animals entered dioestrus, arbitrarily defined as 18 consecutive days without an oestrous vaginal smear. By contrast oestrous cycles ceased within $17.9 \pm 2.0$ days for animals in 10L :14D $\left(P<0.001, \chi^{2}\right.$ test $)$. Cycle length for these mice before reproductive quiescence was $6.8 \pm 0.6$ days.

Spontaneous resumption of oestrous cycles in short photoperiods. Mice rendered acyclic by the short photoperiod eventually resumed their oestrous cycles after $88 \pm 3$ days. Cycle length after resumption of ovarian activity was $7 \cdot 1 \pm 0.4$ days ( 52 cycles), excluding data from the first two highly variable cycles. Cycle length during this phase of the study was longer than during testing in the long photoperiod $(P<0.03)$ but over the same interval cycle length also increased for mice maintained continuously in 14L:10D $(P<0.05)$.

Influence of melatonin on oestrous cycles and reproductive organs. This phase of the experiment was completed by 6 females in $14 \mathrm{~L}: 10 \mathrm{D}$ and 10 in $10 \mathrm{~L}: 14 \mathrm{D}$. One of the females in $14 \mathrm{~L}: 10 \mathrm{D}(17 \%)$ and 6 of those in $10 \mathrm{~L}: 14 \mathrm{D}(60 \%)$ showed regular oestrous cycles $\left(\chi^{2}\right.$ test, $\left.P>0.05\right)$. Three females in $10 \mathrm{~L}: 14 \mathrm{D}$ and 2 in $14 \mathrm{~L}: 10 \mathrm{D}$ had one oestrous smear during the 27 -day testing period.

Ovarian weight was reduced in $14 \mathrm{~L}: 10 \mathrm{D}$ compared to that in $10 \mathrm{~L}: 14 \mathrm{D}$ in mice bearing melatonin capsules $(19.1 \pm 3.5$ compared with $29.0 \pm 2.6 \mathrm{mg}, P<0.03)$. Uterine weight also was lower in $14 \mathrm{~L}: 10 \mathrm{D}$ than in $10 \mathrm{~L}: 14 \mathrm{D}(37.6 \pm 4.5$ compared with $65.3 \pm 6.4 \mathrm{mg}, P<0.008)$. Therefore, females which have experienced ovarian quiescence and reactivation in short photoperiods are less responsive to the inhibitory effects of melatonin on the reproductive apparatus than are females maintained in long photoperiods. 


\section{Discussion}

Short photoperiods inhibited sexual maturation of male grasshopper mice. Complete spermatogenesis was evident in the gonads of long-day mice at 70 days of age and in short-day animals beginning between 120 and 150 days. Similar inhibitory effects of short daylengths have been reported for several vole and mouse species (Brambell \& Hall, 1939; Lecyk, 1962; Hoffmann, 1978; Johnston \& Zucker, 1980a; Whitsett \& Miller, 1982; Dark et al., 1983) but not for other rodents (Reiter et al., 1970; Nelson \& Zucker, 1981).

Suppressive effects of short photoperiod on initial development of the reproductive axis were less pronounced in female than in male grasshopper mice; oestrous vaginal smears were detected in short-day mice 13 days after their first appearance in long-day animals ( 85 compared to 72 days of age). Data from other species are insufficient to discern whether this represents a wide-spread sex difference in the effects of photoperiod on sexual maturation; however, this trend also was evident in white-footed mice (Johnston \& Zucker, 1980a).

Egoscue (1960) and Pinter (1970) reported that northern grasshopper mice became reproductively competent no earlier than 4-6 months of age. The end-point used in their assessments was the production of young, whereas the markers used in the present study were onset of spermatogenesis and development of a cornified vaginal epithelium. These and other differences between the studies may account for the discrepant estimates of the age of puberty.

Responsiveness to short daylengths provides a means for suppressing reproductive development in young born near the end of the breeding season; reproductive development is delayed rather than permanently suppressed by short photoperiods (Hoffmann, 1978; Johnston \& Zucker, 1980a) and the eventual development of refractoriness to the suppressive effects of short daylengths (Bittman, 1978; Reiter, 1980) ensures readiness to breed in overwintering individuals at the very outset of favourable spring conditions (reviewed by Zucker et al., 1980).

The time course for photoperiodic regression and for subsequent redevelopment of the testes is similar among grasshopper mice, Syrian hamsters (Reiter, 1980), white-footed mice (Johnston \& Zucker, 1980c; Lynch \& Wichman, 1981) and meadow voles (unpublished). Spontaneous gonadal redevelopment during prolonged exposure to short photoperiods is widespread among rodents that respond to photoperiod. The development of refractoriness to short daylengths is correlated with the ineffectiveness of exogenous melatonin in regressing the gonads of male Syrian hamsters (Bittman, 1978; Bittman \& Zucker, 1981) and female grasshopper mice (present study).

Although continuous-release melatonin capsules did not alter testicular dimensions or eliminate spermatogenesis, daily melatonin injections late in the light phase induced gonadal regression in grasshopper mice. Similar results have been reported for Syrian hamsters (Carter et al., 1982) but in white-footed mice (Johnston \& Zucker, 1980b) and in Turkish hamsters (Carter et al., 1982) appropriately timed daily injections of melatonin and continuous release of melatonin from capsules regress the testes of animals kept in long daylengths. The basis of these species differences is unknown. Perhaps exposure to high levels of melatonin at inappropriate times of day, as occurs in animals treated with constant-release capsules, de-sensitizes or down-regulates the number of brain receptor binding sites for melatonin (Vacas \& Cardinali, 1979; Reiter, 1980; Zucker \& Carmichael, 1981) in Syrian hamsters and grasshopper mice but not in Turkish hamsters and white-footed mice.

The effectiveness of melatonin in simulating the effects of short photoperiods on the reproductive system suggests that the pineal gland mediates the effects of short daylengths on the grasshopper mouse reproductive axis. Melatonin secretion typically is elevated during a substantial portion of the daily dark phase (Tamarkin et al., 1980); the duration of this melatonin 'pulse' appears to be the critical feature that determines whether the gonads regress or remain functional. It has been suggested (Carter et al., 1982; Carter \& Goldman, 1983) that the duration of the nocturnal melatonin pulse is longer under short than long photoschedules and that this accounts for the differential effects of photoperiod on the gonads. In Djungarian hamsters, daily melatonin 
infusions shorter than $7 \mathrm{~h}$ are consistent with normal gonadal development, whereas daily infusions that exceed $8 \mathrm{~h}$ consistently arrest testicular development (Carter \& Goldman, 1983).

Short photoperiods eliminated oestrous cycles more rapidly in grasshopper mice ( 3 weeks) than in Syrian hamsters (6 weeks; see Seegal \& Goldman, 1975). Oestrous cycles resumed after 13 weeks in grasshopper mice and after 20 weeks in hamsters. Onset of refractoriness to the inhibitory effects of short days occurs sooner for these mice than for hamsters.

Photoperiodic regulation of the gonads is not an invariant characteristic of a given genus or even of a particular species. Depending on local conditions closely related species (Desjardins \& Lopez, 1980), different subspecies (Lynch, Heath \& Johnston, 1981; Dark et al., 1983) and perhaps even different populations of the same subspecies may be differentially responsive to daylength. The reliance on photoperiod as a proximate cue for seasonal reproductive activity is probably related to the degree of environmental predictability of resources used by the local population (Negus \& Berger, 1972).

This research was supported by Grant HD-02982 from the National Institute of Child Health and Human Development. We thank Susan McCamant, Mary Darragh, Emilie Rissman, Margaret Roisman, Clarence Turtle, Phyllis Johnston, Margaret Hamilton and Randy Nelson for assistance during various phases of the study.

\section{References}

Baker, J.R. \& Ranson, R.M. (1932) Factors affecting the breeding of the field mouse (Microtus agrestis). Part I. Light. Proc. R. Soc. 110, 313-322.

Bittman, E.L. (1978) Hamster refractoriness: the role of insensitivity of pineal target tissues. Science, N.Y. 202, 648-650.

Bittman, E.L. \& Zucker, I. (1981) Photoperiodic termination of hamster refractoriness: participation of the pineal gland. Biol. Reprod. 24, 568-572.

Brambell, F.W.R. \& Hall, K. (1939) Reproduction of the field vole, Microtus agrestis hirtus Bellamy. Proc. zool. Soc. Lond. 109, 133-138.

Carter, D.S. \& Goldman, B.D. (1983) Antigonadal effects of timed melatonin infusion in pinealectomized male Djungarian hamsters (Phodopus sungorus sungorus): pulse duration is the critical parameter. Endocrinology (in press).

Carter, D.S., Hall, V.D., Tamarkin, L. \& Goldman, B.D. (1982) Pineal is required for testicular maintenance in the Turkish hamster. Endocrinology 111, 863-871.

Dark, J., Johnston, P.G., Healy, M. \& Zucker, I. (1983) Latitude of origin influences photoperiodic control of reproduction of deer mice (Peromyscus maniculatus). Biol. Reprod. 28, 213-220.

Desjardins, C. \& Lopez, M.J. (1980) Sensory and nonsensory modulation of testis function. In Testicular Development, Structure and Function, pp. 381-388. Eds A. Steinberger \& E. Steinberger. Raven Press, New York.

Egoscue, H.J. (1960) Laboratory and field studies of the northern grasshopper mouse. J. Mammal. 41, 99-110.

Elliott, J.A. (1976) Circadian rhythms and photoperiodic time measurement in mammals. Fedn Proc. Fedn Am. Socs exp. Biol. 35, 2339-2346.

Elliott, J.A. \& Goldman, B.D. (1981) Seasonal reproduction-photoperiodism and biological clocks. In Neuroendocrinology of Reproduction, pp. 377-423. Ed. N. T. Adler. Plenum Press, New York.
Flake, L.D. (1974) Reproduction of four rodent species in a shortgrass prairie of Colorado. J. Mammal. 55, 213216.

Follett, B.K. \& Follett, D.E. (1981) Biological Clocks in Seasonal Reproductive Cycles. Scientechnica, Bristol.

Grocock, C.A. (1981) Effect of different photoperiods on testicular weight changes in the vole, Microtus agrestis. J. Reprod. Fert. 62, 25-32.

Grocock, C.A. \& Clarke, J.R. (1974) Photoperiodic control of testis activity in the vole, Microtus agrestis. J. Reprod. Fert. 39, 337-347.

Hoffmann, K. (1978) Effects of short photoperiods on puberty, growth and moult in the Djungarian hamster (Phodopus sungorus). J. Reprod. Fert. 54, 2935 .

Johnston, P.G. \& Zucker, I. (1980a) Photoperiodic regulation of reproductive development in whitefooted mice (Peromyscus leucopus). Biol. Reprod. 22, 983-989.

Johnston, P.G. \& Zucker, I. (1980b) Antigonadal effects of melatonin in white-footed mice (Peromyscus leucopus). Biol. Reprod. 23, 1069-1074.

Johnston, P.G. \& Zucker, I. (1980c) Photoperiodic regulation of the testes of adult white-footed mice (Peromyscus leucopus). Biol. Reprod. 23, 859-866.

Lecyk, M. (1962) The effect of the length of daylight on reproduction in the field vole (Microtus arvalis pall.). Zoologica Pol. 12, 189-221.

Lynch, G.R. \& Gendler, S.L. (1980) Multiple responses to different photoperiods occur in the mouse, Peromyscus leucopus. Oecologia 45, 318-321.

Lynch, G.R. \& Wichman, H.A. (1981) Reproduction and thermoregulation in Peromyscus: effects of chronic short days. Physiol. \& Behav: 26, 201-205.

Lynch, G.R., Heath, H.W. \& Johnston, C.M. (1981) Effect of geographical origin on the photoperiodic control of reproduction in the white-footed mouse, Peromyscus leucopus. Biol. Reprod. 25, 475-480. 
Negus, N.C. \& Berger, P.J. (1972) Environmental factors and reproductive processes in mammalian populations. In Biology of Reproduction: Basic and Clinical Studies, pp. 89-98. Eds J. T. Velardo \& B. Kaspoons. Bay Publications, Mexico City.

Nelson, R.J. \& Zucker, I. (1981) Photoperiodic control of reproduction in olfactory-bulbectomized rats. Neuroendocrinology 32, 266-271.

Pinter, A.J. (1970) Reproduction and growth for the two species of grasshopper mice (Onychomys) in the laboratory. J. Mammal. 51, 236-243.

Reiter, R.J. (1980) The pineal and its hormones in the control of reproduction in mammals. Endocr. Rev. 1, 109-131.

Reiter, R.J., Sorrentino, S. \& Hoffman, R.A. (1970) Early photoperiodic conditions and pineal antigonadal function in male hamsters. Int. J. Fert. 15, 163-170.

Rissman, E.F. (1980) Prepubertal sensitivity to melatonin in male hamsters. Biol. Reprod. 22, 277-280.

Sadleir, R.M.F.S. (1969) The Ecology of Reproduction in Wild and Domestic Mammals. Methuen, London.

Seegal, R.F. \& Goldman, B.D. (1975) Effects of photoperiod on cyclicity and serum gonadotropins in the Syrian hamster. Biol. Reprod. 12, 223-231.
Tamarkin, L., Reppert, S.M., Orloff, D.J., Klein, D.C., Yellon, S.M. \& Goldman, B.D. (1980) Ontogeny of the pineal melatonin rhythm in the Syrian (Mesocricetus auratus) and Siberian (Phodopus sungorus) hamsters and in the rat. Endocrinology 107, 1061-1064.

Turek, F.W. \& Campbell, C.S. (1979) Photoperiodic regulation of neuroendocrine-gonadal activity. Biol. Reprod. 20, 32-50.

Vacas, M.I. \& Cardinali, D.P. (1979) Diurnal changes in melatonin binding sites of hamster and rat brains. Correlation with neuroendocrine responsiveness to melatonin. Neurosci. Lett. 15, 259-263.

Whitsett, J.M. \& Miller, L.L. (1982) Photoperiod and reproduction in female deer mice. Biol. Reprod. 26, 296-304.

Zucker, I. \& Carmichael, M.S. (1981) Circadian rhythms, brain peptides and reproduction. In Neurosecretion and Brain Peptides, pp. 459-473. Eds J. B. Martin, S. Reichlin \& K. L. Bick. Raven Press, New York.

Zucker, I., Johnston, P.G. \& Frost, D. (1980) Comparative, physiological and biochronometric analyses of rodent seasonal reproductive cycles. Prog. Reprod. Biol. 5, 102-133.

Received 7 February 1983 